Learning from Professional Challenges Identified by School and Institute-based Teacher Educators within the Context of School-University Partnership

Elizabeth White $^{1^{*}}$, Miranda Timmermans $^{2}$ and Claire Dickerson ${ }^{3}$

${ }^{1}$ School of Education, University of Hertfordshire, Hatfield, United Kingdom

*Corresponding Author: e.j.white@ herts.ac.uk

https://orcid.org/0000-0001-5090-1729

Twitter: @ DrEJWhite_Herts

LinkedIn: https://www.linkedin.com/in/liz-white-026b1443/

${ }^{2}$ Avans University of Applied Sciences, Breda, The Netherlands

https://orcid.org/0000-0002-4918-5785

Twitter: @MiraTimm

LinkedIn: https://www.linkedin.com/in/miranda-timmermans-309936/

${ }^{3}$ School of Education, University of Hertfordshire, Hatfield, United Kingdom https://orcid.org/0000-0002-3039-9740 


\title{
Learning from Professional Challenges Identified by School- and Institute-based Teacher Educators within the Context of School-University Partnership
}

\begin{abstract}
Over the last decade, in both the Netherlands and England, there have been national policydriven changes to establish school-based teacher education where the focus is on increased responsibility for schools in initial teacher education. In this research stories were gathered of challenges experienced 'on the ground' by teacher educators in these school-university partnerships. The aim was to explore the reality of working within partnerships for schoolbased teacher education rather than a comparative study between the two countries.

Challenges were identified in guiding and assessing student-teachers; professionalism, growth and well-being of student-teachers and teacher educators; collaborative working in partnerships; and in assuring quality of practice. The stories revealed complexities of working in school-university partnerships across institutional borders and with multiple stakeholders involved. Many teacher educators sought their own solution to the challenges rather than discussing them with others in the partnership. Resolution of challenges was sometimes beyond their control and needed to be dealt with on a different level within the schooluniversity partnership. The stories provide authentic teacher educator voices for use as a professional learning tool in developing collaborative practices in initial teacher education partnerships.
\end{abstract}

\section{Keywords}

school-based teacher educator; institute-based teacher educator; professional learning; school-university partnership 


\section{Introduction}

The evolving environment for teacher education in many OECD (Organisation for Economic Co-operation and Development) countries is leading to partnerships facilitating the formal learning of the next generation of teachers through increased time within schools (Musset 2010; European Commission 2015; White 2018). This has been driven by concerns to improve the quality and supply of teachers. Over the last decade, in both England and the Netherlands, there have been national policy-driven changes to establish school-based teacher education. In the Netherlands about $30 \%$ of student-teachers are educated in partnerships between schools and universities with shared responsibility for student-teachers' education (Auditdienst Rijk 2018), with an intention for this to increase to 100\% (Ministry of Education, Culture and Science 2019). In England in 2018-19, 53\% of postgraduate new entrants were on school-led routes into teaching with reduced or no involvement of a university (Department for Education 2019). In both countries, initial teacher education partnerships have developed where schools have more responsibility for the professional learning and development of student-teachers. Usually both institute-based teacher educators (IBTEs) and school-based teacher educators (SBTEs) are working in these partnerships, where SBTEs are taking on some of the roles previously held by IBTEs (van Velzen and Volman 2009). These SBTEs are often 'dual-role professionals' as they are responsible for teaching pupils and guiding, teaching and/or supervising student-teachers (White, Dickerson, and Weston 2015, 447). In her review, White $(2018,4)$ recognised that this shift in responsibilities requires IBTEs 'reconceptualising their university-based curriculum and professional experiences models, as well as developing partnerships and supporting teachers taking on the role of school-based teacher educators'. Such a reconceptualisation has implications for the professional learning of both IBTEs and SBTEs working in these schooluniversity partnerships. There is a growing body of research into the professional learning of 
IBTEs, but not in relation to this specific aspect of practice. There is little in the literature about the professional learning of SBTEs, or of SBTEs and IBTEs working together in partnerships. Our research explores challenges SBTEs and IBTEs are experiencing in the context of school-based teacher education, and how (or if) the challenges are resolved. Recognition of these challenges and understanding the perspectives of the teacher educators who are dealing with them, will increase our understanding of how teacher educators are working and learning 'on the ground' in initial teacher education partnerships. Collecting stories of challenges in practice will provide a resource bank for creating professional learning tools that provoke reflection and development of collaborative practice.

\section{Theoretical Background}

\section{The Changed Partnership Context in the Netherlands and England}

In the Netherlands there have been significant changes in attitudes and policy since the early 2000's resulting in initial teacher education known as opleiden in de school (school-based teacher education) (Ministry of Education, Culture and Science 1999; Timmermans 2012; Timmermans and van Velzen 2017). Opleiden in de school is based on the principle of 'learning through participation in real, meaningful practices' where school-university partnerships are jointly responsible for the education and assessment of new teachers (Ten Dam and Blom 2006, 649). As this route has grown, more schools have taken on coresponsibility for teacher education, so a transformation of school practice into guided school-based teacher education is needed (van Velzen et al. 2012). In England, changes in policy since 2010 have led to the growth of school-led teacher education, through School Direct routes into teaching (Department for Education 2010; 2011). In both countries there have also been changes to the criteria of initial teacher education with respect to the length of time that student-teachers are in school. The increased time in the workplace brings the 
challenge for teacher educators to provide opportunities that can maximise professional learning by using the school context (Timmermans 2012; van Velzen and Timmermans 2014). A more school-based model for teacher education implies a need for a specific professional learning curriculum and a sociocultural pedagogy for supporting studentteachers learning in school (van Velzen and Volman 2009; Douglas 2017). This in turn has implications for the professional learning and development of teacher educators.

There is a growing body of research on IBTEs, their roles, identity and professional development (Lunenberg, Korthagen, and Swennen 2007; Czerniawski, Guberman, and MacPhail 2017; van der Klink et al. 2017; Dengerink 2019). For SBTEs, what is highlighted is the importance of recognising the role of SBTEs and their value in teacher education, and a need to provide for their professional learning and development in collaborative partnerships with the wider community of teacher educators (Westrup and Jackson 2009; White, Dickerson, and Weston 2015; Smith 2017; Andreasen, Bjørndal, and Kovač 2019).

Partnerships in teacher education may have clearly defined roles and responsibilities for the stakeholders (Velon 2012), or they may be more ambiguous (Mason 2013). In initial teacher education, IBTEs are largely responsible for providing student-teachers with formal knowledge about teaching, supporting reflective practice and teacher development (van Velzen and Timmermans 2014). There may also be an institutional expectation of being engaged in educational research (Boei et al. 2015). In the Netherlands the responsibilities of SBTEs include coordinating the professional development of teachers in their school, supervising student-teachers' school-based experience, and liaising with the university (van Velzen and Timmermans 2014). The responsibility for overseeing the quality of teacher education and verification of the final assessment of the student-teachers lies with the IBTEs, whilst SBTEs are increasingly responsible for the quality of teacher education within their 
school or cluster of schools. In England SBTEs are responsible for assessing, and in the Netherlands for co-assessing, student-teachers. The everyday experiences of teacher educators in practice are evolving, and both SBTEs and IBTEs must develop new ways of working together. This has implications for their professional learning.

\section{Increasing Attention on Teacher Educators' Professional Learning}

Although many European countries have no policy regarding the professional learning of teacher educators (European Commission 2013; Tack et al. 2018), there is mounting attention on their professional development, through formal and informal learning (Ping, Schellings, and Beijaard 2018). This is demonstrated in the Netherlands by increased registration as a teacher educator through the Dutch Association for Teacher Educators (Velon). In England this is illustrated by a new suite of courses to support the professional development of SBTEs and a Professional Framework for Teacher Educators, launched by the National Association of School-based Teacher Trainers (NASBTT).

Dengerink, Lunenberg, and Kools (2015) indicated that Dutch SBTEs and IBTEs have different professional learning preferences. SBTEs were predominantly wanting professional learning around working with the universities and on coaching, while IBTEs were focussed mainly on the pedagogy of teacher education, reflecting their different roles in initial teacher education. Research on the professional learning of experienced IBTEs in different countries has identified a range of foci for the professional learning of the individuals involved (Czerniawski, Guberman, and MacPhail 2017; van der Klink et al. 2017; Ping, Schellings, and Beijaard 2018) including developing their teaching and research skills. This reflects the breadth of their responsibilities around teacher education. IBTEs claim that most of their professional development occurs through informal learning opportunities arising in the 
workplace (Czerniawski, Guberman, and MacPhail 2017; Lunenberg et al. 2017; van der Klink et al. 2017). This is exemplified in the research of van Wessum et al. (2018), where IBTEs shared challenges and discussed different ways to address these challenges in practice, signifying a desire for professional learning to align with problems experienced in practice.

In the Netherlands SBTEs mainly wanted to learn together with colleagues involved in school-university partnerships in their region, while IBTEs wanted to learn individually or with colleagues from their own and other universities (Dengerink, Lunenberg, and Kools 2015). A striking finding from this research is that 'While school-based teacher educators are looking for co-operation with universities, university-based teacher educators do not expect to learn much from school-based teacher educators' (Dengerink, Lunenberg, and Kools 2015, 93). This provides a major incentive to attend to what is happening in partnerships and how mutual beneficial collaboration can be nurtured in the professional development of teacher educators. Finding ways to facilitate such learning within complex initial teacher education partnerships was a key driving force for this research. The context of partnership not only prompts professional development concerns but also provides a community with whom to learn collaboratively, which is believed to be an effective way of learning 'perhaps even more meaningful than individual learning' (van der Klink et al. 2017, 166). Hartmann and Decristan (2018) studied the learning that took place by educational researchers and teachers working together in different activities across their institutional boundaries. They showed that learning took place at the level of identification of practices (their values, contributions and differences); co-ordination of activities across the boundary to improve the efficiency of joint work; reflection on the perspective of the different participants; and transformation of practice, potentially hybridising elements from both fields. There is potential for IBTEs and 
SBTEs to transform the practice of initial teacher education through learning together about challenges they are experiencing and need to resolve within their partnerships.

In the Netherlands the shift from institution-based to school-based teacher education has developed gradually for the first decade (van Velzen and Timmermans 2017), then more rapidly, with a regulated structure (NVAO 2009; 2018), specific funding to build and sustain the partnership (Ministry of Education, Culture and Science 2019) and opportunities for SBTEs and IBTEs to learn collaboratively, facilitated by a supportive programme leading to registration with Velon (Boei et al. 2015). In contrast, in England the shift to school-based teacher education has been rapid and more varied in structure (Brown, Rowley, and Smith 2016), without specific funding for building and sustaining partnerships, and with separate associations dedicated to supporting SBTEs (NASBTT) and IBTEs (UCET, the Universities Council for the Education of Teachers), which cooperate increasingly at leadership level, but are not yet offering collaborative professional development programmes or registration. Additionally, the professional learning of new SBTEs has been a developing aspect of the role of universities in school-led partnerships (White, Dickerson, and Weston 2015).

\section{Stories of Challenges}

Challenges or dilemmas experienced in practice are a useful provocation for teacher educators to articulate their practice and the thinking that underpins it. Dilemmas recognised by teacher educators during their teaching have been used to explore their beliefs and practice concerning teaching student-teachers (Tillema and Kremer-Hayon 2005; Cabaroglu and Tillema 2011). Using stories, Tillema and Kremer-Hayon (2005) were able to identify where teacher educators attributed tensions experienced in constructing their pedagogy of teacher education, recognising external (i.e. conditions, student-teachers) as well as internal sources 
(i.e. approaches, self). A challenge in practice can be documented as a 'story', which Scholes $(1980,210)$ described as 'a narrative with a certain very specific syntactic shape (beginningmiddle-end or situation-transformation-situation) and with a subject matter which allows for or encourages the projection of human values upon this material.' Stories allow complex and ambiguous phenomena to be captured and personal values to be expressed (Scholes 1980; Carter 1993). In their work with teachers, Drake, Spillane, and Hufferd-Ackles $(2001,2)$ highlighted the value of stories to professionals noting that 'Stories, as lived and told by teachers, serve as the lens through which they understand themselves personally and professionally and through which they view the content and context of their work...'. Stories hold the potential for reflecting on practice and for transformative learning and have been employed helpfully in both research and professional learning (Jarvis 2005; Pauw et al. 2017). In this research stories have been used to surface the perspective of the teacher educator experiencing a challenge in practice. These, often hidden, perspectives may provide a rich source of learning for partnership working in teacher education.

\section{Research Focus and Questions}

The research question was: What challenges in practice are identified by teacher educators working in initial teacher education partnerships? The sub questions were:

1. What was the content of the challenge?

2. Who was involved in the challenge?

3. How was the challenge dealt with?

This will increase our knowledge and understanding of the types of challenges that are occurring in the changed context of school-university partnerships; the number and variety of stakeholders involved; and the ways that teacher educators are managing these challenges. 
This professional learning has the potential to enhance partnership working in teacher education.

\section{Methodology}

An exploratory case study was carried out, of challenges experienced 'on the ground' by teacher educators in school-university partnerships where the focus is on collaborative responsibility for initial teacher education.

\section{Data gathering}

Qualitative data were collected as stories from IBTEs, and from SBTEs who were coordinating the professional learning of teachers in their schools, and/or who were taking on the traditional mentoring role. A purposeful sampling approach was used (Patton 2015), to gather information-rich cases to illustrate what is happening in school-based teacher education within school-university partnerships for initial teacher education, in England and the Netherlands. Participants were invited through face-to-face conversations at workshops for teacher educators held at the Annual Conference of the Association of Teacher Educators in Europe and at the University of Hertfordshire in 2018 or by email to teacher educators from within the researchers' own networks. SBTEs and IBTEs were included, to provide their different perspectives on partnership working in school-based teacher education. IBTEs and SBTEs were approached who were working in primary, secondary and vocational education, to surface challenges experienced across the range of school-university partnerships. 35 different teacher educators shared their stories, written in their own language. 
Respondents were asked to write a brief story, in Dutch or English, of a specific challenge faced in recent practice, using pseudonyms, including a beginning and a plot and an ending (if there was one). This was in recognition that some challenges might not have needed a resolution or had gone beyond resolution, while some stories might have been written before a resolution had been found.

Prompt questions were provided:

- What was the real challenge for you?

- Where did the challenge arise?

- How did you deal with it?

- How did that work?

The teacher educators were provided with an example story from a different context for story-writing guidance (Pauw et al. 2017). The researchers followed the appropriate ethical guidelines for data collection and participants took part voluntarily and gave their informed consent.

\section{Coding procedure}

The bilingual researcher, who was a native Dutch speaker and had first-hand experience of the school-university partnership context in the Netherlands, translated the Dutch stories with the aid of Google Translate. The bilingual researcher and one of the other researchers discussed the terminology and meaning of the stories together checking to ensure that the translations reflected the original meaning, to retain 'concept validity' (Shklarov 2007, 531), appreciating that language translation is not a simple linguistic exercise. The researchers worked together on the thematic analysis and could go back to the original Dutch text if that seemed to be necessary. Thematic analysis was employed as 'a method for systematically 
identifying, organising, and offering insight into patterns of meaning (themes) across a data set' (Braun and Clarke 2012, 57).

Initially a thematic analysis of the stories was carried out using an inductive approach (Braun and Clarke 2006) where the stories were repeatedly read and coded for aspects of practice within the stories. This stage involved a process of 'familiarization' during which the researchers became "“immersed" in the data' (Braun et al. 2018, 10), including translating and discussing terminology and meaning. Sixteen aspects or subthemes were identified, which were grouped into four themes: guiding and assessing student-teachers; professionalism, growth and well-being of student-teachers and teacher educators; collaborative working; and quality of practice. These themes were then used deductively with the stories to identify any further occurrences. Finally, all the stories were reviewed to identify: what are the challenges that teacher educators identify in their work? who is part of the story? and how do teacher educators cope with or manage these challenges in their practice?

\section{Results}

35 teacher educators wrote stories about their professional practice in the current context, 10 from IBTEs and 25 from SBTEs (Table 1). The stories had between 226 and 1152 words, varying in degree of reflection from those that were descriptive, to those that revealed the internal thoughts and feelings of the author. Some of the challenges in the stories arose externally from the author, and some were internal challenges. For example, an externally arising challenge occurred where a student-teacher was not making expected progress. An internal challenge arose from dealing with personal insecurities involved in leading professional learning for colleagues. 


\section{Insert Table 1}

\section{What was the content of the challenge?}

The stories revealed challenges in the guiding and assessing of student-teachers; professionalism, growth and well-being; collaborative working; and quality of practice. Tables 2-5 show the number of incidences and subthemes associated with each of these four themes. Some stories were multi-layered and covered more than one theme, especially when there were multiple actors. For example, the IBTE who recounted a story of nurturing the personal and professional growth of a student-teacher through a challenging school-based placement, therefore the IBTE also had to work with the teacher mentor to support the provision of appropriate learning opportunities for the student-teacher. Excerpts from stories are used in this section to illustrate the content and variety of the challenges and to demonstrate their richness and emotionality.

\section{Theme 1: Guiding and assessing student teachers}

More than three-quarters of the stories included challenges about guiding and assessing student teachers (Table 2). In one of these a student-teacher's teaching was assessed 'as inadequate'; as the SBTE explained: '... the development we saw in this student wasn't sufficient; the student didn't react adequately to pupils' behaviour and needs'. In another example, which involved helping student-teachers to learn from their workplace experiences, an IBTE reflected '... not every school provides optimal learning opportunities for studentteachers to work on this [pupil data] task. The student-teacher therefore can't perform all professional activities properly.' Other stories covered issues such as: supporting a teacher mentor in guiding the student-teacher's learning and judicious assessment of their progress; and working with student-teachers who were not engaged with learning. 


\section{Insert Table 2}

\section{Theme 2: Professionalism, growth and well-being}

The sometimes sudden and unexpected nature of a challenge is conveyed in the following excerpts from two IBTEs' stories associated with the theme of professionalism, growth and well-being (Table 3). The first, relating to a student-teacher's 'unprofessional attitude', arose during an assessment interview when the teacher mentor announced "“This student teacher will not pass"'. The IBTE continued 'Everyone was shocked, what had happened, what had changed? The first assessment seemed positive, and now this?' The second case entailed helping a student-teacher, Michael, to move on after a difficult issue at school. The IBTE reflected: 'Like Michael, I was also affected. What was the best way to guide him working with his colleagues?' Other stories within this theme dealt with challenges such as: working with a critical student-teacher who alienated other members of staff; facing tensions in taking on the SBTE role; coaching a student-teacher who was not afforded the rich learning environment needed; and responding to signs of a mental health issue in a student-teacher.

\section{Insert Table 3}

\section{Theme 3: Collaborative working}

Collaborative working challenges were identified in more than a third of the stories (Table 4). In one of these, an IBTE was working with SBTEs who were not readily cooperating with the university. Another two challenges involved SBTEs working in vocational settings. One of these SBTEs was dealing with communication at all levels between the university and the school; the other was coaching a good student-teacher and colleague without support in the end from the Head/Director. The complexity of collaborative working is illustrated by the story in which an SBTE highlighted three aspects to their dilemma: their '.. double-role: 
SBTE and facilitator of the support group'; issues '... to do with the question "“Who is responsible for the student teacher's learning?"'; and matters '... to do with communication between the HEI and school'.

\section{Insert Table 4}

\section{Theme 4: Quality of Practice}

Only five of the stories were thought to relate to quality of practice (Table 5). Two of these were stories from SBTEs, which involved: choosing to change the mentor to support a student-teacher to make progress; and tensions in teaching colleagues to coach studentteachers on reflection. In a third example, an SBTE questioned 'How could we provide training in which mentors really got motivated and came to learn?' and then described how they improved the training, using feedback from mentors and giving them a voice. Reflecting on their learning from dealing with this challenge, the SBTE concluded 'We are not just teaching, but we are learning together!'

\section{Insert Table 5}

\section{Who was involved in the challenge?}

34 of the stories had an SBTE in them, 20 had an IBTE and 19 of these had both an IBTE and SBTE in them. 30 involved at least one student-teacher, four stories involved SBTEs and IBTEs without student-teachers being directly involved and one story involved just an experienced SBTE working with a new SBTE. 15 of the stories with a student-teacher in them involved both an IBTE and an SBTE. There were 19 stories featuring a teacher mentor. There were seven stories which featured other stakeholders like principals and parents of pupils. In 15 stories, three people played a role and in 12 stories there were four or more stakeholders. 


\section{How was the challenge dealt with?}

Twenty-nine stories reported having some success towards a desired outcome. In many stories the challenges were resolved for all the stakeholders, revealing a range of approaches employed by teacher educators in the workplace. For example, the SBTE who had a hardworking student-teacher in their school, with whom the mentor had built a good relationship, however the student-teacher was not making sufficient progress. Within this story a difficult decision needed to be made and the teacher educator identified actions to help them consider all the evidence, to be able to make a well-founded decision. Where there was some resolution to the challenge, the teacher educators usually did not appear to collaborate to find solutions, even though most of the time many people were part of the challenge.

Additionally, there was no explicit mention of seeking solutions from the literature.

The teacher educators often used a combination of different actions, seen together as their strategy. Many chosen strategies were unique to the challenge. Some challenges were experienced and solved in the moment; some were experienced over time with the solution gradually evolving; and a few were known or anticipated by the teacher educators beforehand, who then reflected on an appropriate strategy to adopt. Some challenges arose during action and required immediate response.

Some challenges described were only partially resolved. For example, a teacher educator was able to bring about a compromise to meet the differing requirements between the school and the university for one student-teacher, providing a temporary solution. However, this did not fully resolve the issue that needed to be addressed at partnership level about the lack of alignment in pedagogical approach between the school and the university. 
Five stories reported challenges that were not solved. Two of these stories only identified the challenge, and not how it was dealt with; one of the teacher educators gave up on dealing with the challenge because the initial result of an intervention was unsuccessful; the other two were beyond the sphere of influence of the teacher educators. Unresolved challenges revealed a number of barriers to resolution. For example: the dual role of coaching and assessing a student-teacher; a lack of clarity as to exactly where responsibility lay for studentteacher learning; communication between the university and the school; and the need for the school leadership to be committed to the initial teacher education partnership.

\section{Discussion}

\section{The content of the challenges}

The context within school-university partnerships where the responsibility for teacher education has shifted increasingly towards schools has altered the nature of the work of both SBTEs and IBTEs and the way that they work together in both countries (van Velzen and Volman 2009; White, Dickerson and Weston 2015). A wide range of challenges was identified in the stories of teacher educators working in these partnerships, from guiding student-teachers in all aspects of their development, assessing student-teachers and working collaboratively and professionally in partnerships to provide high quality teacher education. Although the stories were collected from teacher educators working in different settings, the themes that have arisen from the data suggest that most of the content of the stories is recognisable in the professional work of teacher educators (Tables 2-5).

Many of the challenges identified were not new to the profession. For example, the problem around when to fail a student-teacher and how to have that difficult conversation, and the 
issue around ensuring student-teachers have access to appropriate learning opportunities in school. However, the new context has meant that SBTEs were experiencing challenges that were previously in the domain of IBTEs, such as dealing with student-teachers who were not engaged with the learning in taught sessions. IBTEs were also facing new challenges because there were more stakeholders involved in initial teacher education, for example, working with a group of SBTEs who were not readily cooperating with the university. Where the challenges were not new the context has changed, leading to a need to understand the perspectives of the other stakeholders in order to work towards resolution.

By writing stories, the teacher educators revealed genuine tensions in their practice and aspects of practice where they would like to have more resources to draw on. This reflects their own, often unconscious, professional learning needs. These may be different from the professional development needs identified when asked directly in research surveys (Czerniawski, Gubermans and MacPhail 2017; van der Klink et al. 2017). This means that the stories have the potential for development into a tool for teacher educator professional learning.

The English stories included SBTEs who were finding their new responsibility in assessing student-teachers a challenge. There were SBTEs having similar challenges around assessment in the Dutch school-university partnerships, even though this is a shared role between IBTE and SBTE. This suggests that whether responsibility is shared or not, assessment of schoolbased practice is a cause of tension for teacher educators.

By examining the stories of challenges in practice it was possible to attribute some to external sources regarding other stakeholders in the partnership, resources or opportunities and some 
internally from reflection on practice and identity. Internal tensions may indicate a need to reconceptualise practice, whereas external dilemmas may call for a restructuring of conditions (Tillema and Kremer-Hayon 2005).

\section{Approaches to resolving challenges}

The stories demonstrate the complexity of the current working context for these teacher educators, revealing the wide range of actions that they employ to resolve challenges. Cabaroglu and Tillema $(2011,560)$ suggest that 'Developing strategies for dealing with dilemmas calls for high level of professional thinking ..., as it involves weighing alternatives for action ..., and decide [sic] upon the one which best meets specific needs ...'. However, most of the stories did not explicitly design a strategy, choosing a sequence of actions, but resolution seemed to come from trial and error. The teacher educators usually did not explicitly identify possible alternatives for action, which can be critical in successful resolution of a dilemma.

Partial resolution of difficulties demonstrated the reality of working in partnerships that cross boundaries between settings. Many of the challenges were multi-layered, involving those who are working with student-teachers from day to day, and those who are running partnerships at strategic levels in both school and university. It appears that resolution of unresolved challenges might have been possible if timely action had been taken.

There are many stakeholders involved in school-university partnerships including teacher educators, student-teachers, school leaders and parents who feature in these stories, reflecting the necessity for teacher educators to learn how to manage multiple relationships effectively and to support student-teachers to do this as well. This work takes place in a negotiated space, 
yet it appeared that most of the owners of a challenge sought their own solution from within, not explicitly from literature nor from across the partnership through collaboration. It is clear to see then that moving initial teacher education into school, without creating a space for collaborative professional learning, can result in impoverished practice (Smith 2017).

\section{Conclusion}

This study demonstrates the range of complex challenges that teacher educators are negotiating in initial teacher education partnerships and increases our understanding of how they are learning to deal with these challenges. The authentic stories of teacher educators revealed that many teacher educators sought their own solution to the challenges rather than discussing them with others in the partnership, so indicating the importance of providing for collaborative professional learning and development.

Personal stories can enable professionals to reflect on, and transform, their own practice (Drake, Spillane, and Hufferd-Ackles 2001; Jarvis 2005; Pauw et al. 2017). Additionally, reflecting on challenges together in partnerships encourages and gives support to further learning on the perspectives of other stakeholders. Van der Klink et al. (2017) proposed that 'organizing team-related ways of working could have a significant impact on teacher educators' professional development', suggesting that learning experiences within a team or local community may be more meaningful than individual learning. The research of Westrup and Jackson (2009) found that IBTEs and SBTEs felt a need for a community where they could develop their professional knowledge and understanding together as teacher educators, rather than having taught sessions for their professional learning, revealing a need for ownership and autonomy. The use of these stories about challenges in practice can afford a means by which collaborative learning can take place within a team, enhancing the impact on 
professional learning and providing a boundary crossing tool that can support teacher educators to work together in a collaborative space as a professional learning community. Additionally, discussing these stories can help to provide role clarity and increase the selfefficacy of teacher educators (Andreasen, Bjørndal, and Kovač 2019).

In 2015, the European Commission's report to improve initial teacher education called for 'mutual sharing between policy makers and education professionals of the benefits of and good practice in collaborative learning ... to exchange good practice, experience and learning outcomes' $(2015,49)$. They recognised that 'collaborative learning produces results on a rather long-term basis, and priorities in educational systems often change with political cycles. Thus, the sustainability of collaborative learning environments is of key importance' (European Commission 2015, 50). In order to provide a resource for such collaborative learning, the stories that were collected have been developed into tools that can be used to stimulate reflection and discussion about practice and to share insights that can be used in the professional development of teacher educators in collaborative contexts as well as for SBTEs and IBTEs to use independently. Such informal learning is a powerful way of coping with challenges faced by teacher educators and provides a way to support them to cross boundaries more seamlessly and to reflect critically on their practice. The stories and supporting material are available in English on the FLiTE (For Learning in Teacher Education) website and will also be available in Dutch. Preliminary observations from workshops using the resources reveal particular benefit when both IBTEs and SBTEs use the tools together to explore their practice, opening opportunities to experience new perspectives (White, Timmermans and Dickerson, in press). 
Through provision and use of these research-informed tools for professional development, teacher educators and researchers can: contribute new approaches for re-affirming democratic practices in initial teacher education; nurture sustainable collaborative partnerships in challenging contexts; and thereby meet an identified professional development need (White, Dickerson and Weston 2015). We believe that these resources have the potential to help stakeholders to reflect on different perspectives, providing an opportunity for enhancing the quality of initial teacher education at the level of teacher educators and partnerships. Exploring challenges that were experienced 'on the ground' in school-based teacher education has shed light on how the intentions of school-based teacher education were being implemented in practice.

\section{Limitations}

A limitation of this research is that the stories do not provide a comprehensive list of challenges experienced by teacher educators working in partnerships, nor can the frequency with which challenges occurred in some aspects of practice provide an understanding of which challenges are most frequently experienced in practice. This is because the case study was small scale and exploratory in nature and because of the directive role that the researchers took in collecting the data. There were more stories collected from SBTEs than IBTEs, which may reflect their desire to learn more in and about collaboration in partnerships than IBTEs (Dengerink, Lunenberg, and Kools 2015).

\section{Recommendations}

In future research it would be interesting to have the stories of more IBTEs so that the experiences of SBTEs and IBTEs could be compared, or to have the stories of both SBTE and IBTE around the same issue. Many of the stories were rich in description, but they could 
have been richer if the teacher educators had more help in developing their story-writing skills, as well as an example (Pauw et al. 2017). Additionally, having a scaffold to support story-writing could have prompted the approaches taken to resolve the challenge to be written explicitly within the stories.

Developing the professional knowledge, skills and attributes to be able to deal with many of these challenges will involve experiential and collaborative learning over time. What is important is to learn from challenges in practice, and if a solution is needed, realise who should be involved in working it out. So, rather than asking 'What is the solution to the challenge?' we can ask 'What learning can we get from this challenge?'; 'Is a solution needed?' and 'Who should be involved in working out the solution?'. Additionally, the challenges that have been surfaced in these stories provide us with an opportunity for a different type of learning, beyond procedural learning, but a way of developing the attributes that define a teacher educator. This could involve the transformative learning that Jarvis (2005) suggested can be associated with using story.

The stories make it clear that teacher educators are an increasingly diverse group, making it important that all who are working together in school-university partnerships understand their own contribution to teacher education, and these contributions need to be considered in developing a pedagogy of teacher education. Each challenge in practice that surfaced in the stories may indicate an area of professional learning that should be considered as part of a professional learning curriculum for teacher educators in school-university partnerships. The stories could help teacher educators to be better prepared, have a greater range of strategies to call upon and a greater understanding of the perspectives of those involved in the challenge, and preferred partnership approaches. In collaborative professional learning these stories can 
provide helpful stimuli for mixed groups of IBTEs and SBTEs to understand the perspectives of others in the partnership. Deliberating together on the root of such challenges, and objectively considering some of the barriers to their resolution before issues arise, would be beneficial in order to resolve anomalies. By sharing challenges in practice, such as these, and possible alternatives for action within the negotiated space that partnerships are working in, it may be possible to develop a higher level of professional thinking, enabling teacher education to become a fully shared responsibility between the university and school (van der Klink et

al. 2017; Hartmann and Decristan 2018). Conversations may be needed at the leadership level of the partnership, as well as between teacher educators 'on the ground' to surface differing expectations between institutions and to seek to find a way to bring working practices into closer alignment, in order to avoid similar problems in the future (Smith 2017). Such conversations can involve different philosophical standpoints regarding education and the responsibilities of different stakeholders, challenging the very existence of partnerships.

\section{Acknowledgments}

This work was supported by the University of Hertfordshire under Grant C004364.01.

\section{Declaration of interest statement}

No potential conflict of interest was reported by the authors

\section{References}

Andreasen, J. K., Bjørndal, C. R. P., and Kovač, V. B. 2019. "Being a teacher and teacher educator: The antecedents of teacher educator identity among mentor teachers." Teaching and Teacher Education, 85, 281-291. doi:10.1016/j.tate.2019.05.011.

Auditdienst Rijk. 2018. Financiering Opleiden in de School. Eindrapport [Financing 
school-based teacher education. End report.] 's Gravenhage: Ministerie van Financiën. Boei, F., Dengerink, J., Geursen, J., Kools, Q., Koster, B., Lunenberg, M., and Willemse, M. 2015. "Supporting the professional development of teacher educators in a productive way." Journal of Education for Teaching, 41(4), 351-368. doi:10.1080/02607476.2015.1080403. Braun, V., and Clarke, V. 2006. Using thematic analysis in psychology. Qualitative Research in Psychology, 3, 77-101.

Braun, V., and Clarke, V. 2012. “Thematic Analysis.” In H. Cooper (Ed), APA Handbook of Research Methods in Psychology: Vol. 2. Research Designs. (pp. 57-71). Washington, DC: APA books. doi.org/10.1037/13620-000.

Braun, V., Clarke, V., Hayfield, N., and Terry, G. 2018. “Thematic Analysis.” In P. Liamputtong. (Ed), Handbook of Research Methods in Health Social Sciences. (pp. 1-18). Singapore: Springer Nature. doi:10.1007/978-981-10-2779-6_103-1.

Brown, T., Rowley, H. \& Smith, K. 2016. The beginnings of school led training: New challenges for university teacher education, School Direct research project final report. Manchester Metropolitan University.

Cabaroglu, N., and Tillema, H. H. 2011. "Teacher educator dilemmas: a concept to study pedagogy." Teachers and Teaching, 17(5), 559-573. doi:10.1080/13540602.2011.602210. Carter, K. 1993. "The Place of Story in the Study of Teaching and Teacher Education." Educational Researcher, 22, 5-18. doi: 10.3102/0013189X022001005.

Czerniawski, G., Guberman, A., and MacPhail, A. 2017. “The professional developmental needs of higher education-based teacher educators: an international comparative needs analysis.” European Journal of Teacher Education, 40(1), 127-140.

doi:10.1080/02619768.2016.1246528.

Dengerink, J. 2019. Lerarenopleiders in ontwikkeling. Een surveystudie naar het werk en de professionaliseringsbehoeften van lerarenopleiders in het hoger onderwijs. 
Onderzoeksartikel. Tijdschrift voor Lerarenopleiders, 40(1), 1-17. [Teacher Educators in development. A survey study into the work and professionalization needs of teacher educators in higher education. Research article. Dutch Journal for Teacher Educators.] Dengerink, J., Lunenberg, M., and Kools, Q. 2015. "What and how teacher educators prefer to learn.” Journal of Education for Teaching, 41(1), 78-96.

doi:10.1080/02607476.2014.992635.

Department for Education. 2010. The Importance of Teaching: Schools White Paper. Retrieved from https://www.education.gov.uk/publications/standard/publicationdetail/page1/CM\%207980. Department for Education. 2011. Training our next generation of outstanding teachers. Retrieved from https://www.gov.uk/government/publications/training-our-next-generationof-outstanding-teachers-an-improvement-strategy-for-discussion.

Department for Education. 2019. Initial Teacher Training (ITT) Census for 2019 to 2020, England. Retrieved from https://assets.publishing.service.gov.uk/government/uploads/system/uploads/attachment_data /file/848851/ITT_Census_201920_Main_Text_final.pdf. Contains public sector information licensed under the Open Government Licence v3.0.

Douglas, A. S. 2017. "Raising the standard: contradictions in the theory of student-teacher learning." European Journal of Teacher Education, 40(2), 157-170. doi:10.1080/02619768.2017.1281910.

Drake, C., Spillane, J. P., and Hufferd-Ackles, K. 2001. "Storied identities: Teacher learning and subject-matter context." Journal of Curriculum Studies. 33(1), 1-23. doi:10.1080/00220270119765. 
European Commission. 2013. Supporting Teacher Educators for better learning outcomes. Retrieved from http://ec.europa.eu/education/policy/school/doc/support-teachereducators_en.pdf

European Commission. 2015. Shaping career-long perspectives on teaching. A guide on policies to improve Initial Teacher Education. Retrieved from http://ec.europa.eu/dgs/education_culture/repository/education/library/reports/initial-teachereducation_en.pdf Hartmann, U. and Decristan, J. 2018. "Brokering activities and learning mechanisms at the boundary of educational research and school practice." Teaching and Teacher Education, 74, 114-124. doi:10.1016/j.tate.2018.04.016.

Jarvis, J. 2005. "Telling stories in class: an exploration of aspects of the use of narrative in a higher education context." Journal for the Enhancement of Learning and Teaching 2 (1):613. Retrieved from https://uhra.herts.ac.uk/handle/2299/2582 Lunenberg, M., Korthagen, F., and Swennen, A. 2007. "The teacher educator as a role model." Teaching and Teacher Education, 23, 586-601. doi: 10.1016/j.tate.2006.11.001. Lunenberg, M., Murray, J., Smith, K., and Vanderlinde, R. 2017. “Collaborative teacher educator professional development in Europe: different voices, one goal." Professional Development in Education, 43(4), 556-572. doi:10.1080/19415257.2016.1206032.

Mason, K. O. 2013. "Teacher involvement in pre-service teacher education.” Teachers and Teaching, 19, 559-574. doi:10.1080/13540602.2013.827366.

Ministerie van Onderwijs, Cultuur en Wetenschap. 2019. "Regeling van de Minister van Onderwijs, Cultuur en Wetenschap en de Minister voor Basis- en Voortgezet Onderwijs en Media van 12 juli 2019, nr. 9161960, houdende regels voor het verstrekken van subsidie ten behoeve van opleidingsscholen (Regeling tegemoetkoming kosten opleidingsscholen 2019)." [Ministry of Education, Culture and Science. 2019. Regulation of the Minister of Education, 
Culture and Science and the Minister for Primary and Secondary Education and Media of 12 July 2019, no. 9161960, containing rules for the granting of subsidies for training schools (Regulations for the reimbursement of costs for training schools 2019)]. stcrt-2019-41840. SGravenhage, 12 juli. https://zoek.officielebekendmakingen.nl/stcrt-2019-41840.html Ministerie van Onderwijs Cultuur en Wetenschap. 1999. "Maatwerk voor morgen: het perspectief van een open onderwijsarbeidsmarkt.” [Ministry of Education, Culture and Science. 1999. Teacher education for tomorrow: the perspective of an open educational labour market.] Zoetermeer.

Musset, P. 2010. "Initial Teacher Education and Continuing Training Policies in a Comparative Perspective: Current Practices in OECD Countries and a Literature Review on Potential Effects." OECD Education Working Papers, 48. doi.org/10.1787/5kmbphh7s47hen.

NVAO. 2009. Toetsingskader opleidingsschool. Den Haag: Nederlands Vlaamse accreditatie organisatie \& Inspectie van het Onderwijs. [Assessment framework for Partnerships School based Teacher Education. Den Haag: The Accreditation Organisation of the Netherlands and Flanders (NVAO) \& Inspectorate of Education]

NVAO. 2018. Protocol Toetsingskader en -procedure. Aspirant-opleidingsschool Den Haag: Nederlands Vlaamse accreditatie organisatie \& Inspectie van het Onderwijs.

[Protocol Assessment framework and procedure for Aspirant Partnerships School-based Teacher Education. Den Haag: The Accreditation Organisation of the Netherlands and Flanders (NVAO) \& Inspectorate of Education.]

Patton, M. Q. 2015. Qualitative research \& evaluation methods: integrating theory and practice, Thousand Oaks, California, SAGE Publications, Inc. 
Pauw, I., van Lint, P., Gemmink, M., Jongstra, W., and Pillen, M. 2017. Een leraar als geen ander. Ontwikkeling van professionele identiteit van leraren door verhalen. [A teacher like no other. Developing teachers' professional identity through narratives]. Garant: AntwerpenApeldoorn

Ping, C., Schellings, G. L. M. and Beijaard, D. 2018. “Teacher educators' professional learning: A literature review." Teaching and Teacher Education, 75, 93-104. doi:10.1016/j.tate.2018.06.003.

Scholes, R. 1980. "Language, narrative, and anti-narrative.” Critical Inquiry, 7(1), 204-212. doi.org/10.1086/448096.

Shklarov, S. 2007. "Double vision uncertainty: The bilingual researcher and the ethics of cross-language research." Qualitative Health Research, 17, 529-538. doi.org/10.1177/1049732306298263.

Smith, K. 2017. "Learning from the past to shape the future." European Journal of Teacher Education, 40, 630-646. doi:10.1080/02619768.2017.1385058.

Tack, H., Valcke, M., Rots, I., Struyven, K. and Vanderlinde, R. 2018. "Uncovering a hidden professional agenda for teacher educators: A mixed method study on Flemish teacher educators and their professional development." European Journal of Teacher Education, 41, 86-104. doi:10.1080/02619768.2017.1393514.

Ten Dam, G. T. \& Blom, S. 2006. "Learning through participation. The potential of schoolbased teacher education for developing a professional identity." Teaching and teacher education, 22, 647-660. doi.org/10.1016/j.tate.2006.03.003.

Tillema, H., and Kremer-Hayon, L. 2005. "Facing dilemmas: teacher-educators' ways of constructing a pedagogy of teacher education." Teaching in Higher Education, 10(2), 203217. doi:10.1080/1356251042000337954. 
Timmermans, M. 2012. "Kwaliteit van de Opleidingsschool. Over affordance, agency en competentieontwikkeling." [Quality of Professional Development Schools]. Dissertatie. Thesis. Tilburg: Universiteit Tilburg.

Timmermans, M. and C. Van Velzen. 2017. "Samen in de School Opleiden.” [Teaching together in school-based partnerships.] Kennisbasis Lerarenopleiders [Knowledge base of Teacher Educators], Katern 4. Breda: Velon.

van der Klink, M., Kools, Q., Avissar, G., White, S., and Sakata, T. 2017. "Professional development of teacher educators: what do they do? Findings from an explorative international study." Professional Development in Education, 43(2), 163-178. doi:10.1080/19415257.2015.1114506.

van Velzen, C., and Timmermans, M. 2014. "What can we learn from the shift towards a more school-centred model in the Netherlands?" In K. Jones and E. White (Eds.), Developing outstanding practice in school-based teacher education. (pp. 56-63). Northwich: Critical Publishing.

van Velzen, C., and Timmermans, M. 2017. Opleiden in de school / in de school opleiden. In M. Timmermans \& C. Van Velzen (Eds.), Samen in de school opleiden. Katern 4. Kennisbasis Lerarenopleiders (pp. 9-22). Breda: Vereniging Lerarenopleiders Nederland (VELON). [School-based Teacher Education. In M. Timmermans \& C. Van Velzen (Eds.), Teaching together in school-based partnerships. Knowledge base of Teacher Educators] van Velzen, C., and Volman, M. 2009. "The activities of a school-based teacher educator: a theoretical and empiricial exploration." European Journal of Teacher Education, 32(4), 345367. doi:10.1080/02619760903005831.

van Velzen, C., Volman, M., Brekelmans, M., and White, S. 2012. “Guided work-based learning: Sharing practical teaching knowledge with student teachers." Teaching and Teacher Education, 28, 229-239. doi.org/10.1016/j.tate.2011.09.011. 
van Wessum, L., Kools, Q., Boei, F., Willemse, M., and van Katwijk, L. 2018. “Onderzoek naar professionaliseringsactiviteiten bij HBO-lerarenopleiders in het doen en begeleiden van praktijkonderzoek.” [Research into professional development activities: HBO teacher educators in conducting and supervising practical research] Tijdschrift voor lerarenopleiders, 39(1), 53-64.

Velon. 2012. "Beroepsstandaard voor lerarenopleider.” [Professional Standards for Teacher Educators] https://velon.n1/beroepsregistratie/beroepsstandaard/

Westrup, R., and Jackson, A. 2009. “The Professional Development Needs of Teacher Educators in Higher Education Institutions (HEIs) and School-based Mentors in Schools." Retrieved from https://www.heacademy.ac.uk/knowledge-hub/professional-development$\underline{\text { needs-teacher-educators-higher-education-institutions-heis. }}$

White, E., Dickerson, C., and Weston, K. 2015. "Developing an appreciation of what it means to be a school-based teacher educator." European Journal of Teacher Education, 38(4), 445-459. doi:10.1080/02619768.2015.1077514.

White, E., Timmermans, M. and Dickerson, C. (in press). "Learning from stories about the practice of teacher educators in partnerships between schools and higher education institutions.” In J.M.H. Swennen and E. White (Eds.), Being a Teacher Educator: ResearchInformed Methods for Improving Practice. Abingdon: Routledge.

White, S. 2018. “Teacher educators for new times? Redefining an important occupational group.” Journal of Education for Teaching. doi: 10.1080/02607476.2018.1548174. 
Table 1 Participants by country, role and work context

\begin{tabular}{|l|l|l|l|l|l|l|}
\hline & \multicolumn{2}{l|}{ England } & \multicolumn{2}{l|}{ Netherlands } & Total \\
\hline & SBTE & IBTE & SBTE & IBTE & \\
\hline Primary & 1 & & 8 & 2 & 11 \\
\hline Secondary & 12 & 2 & 1 & 6 & 21 \\
\hline Vocational/ Further Education & & & 3 & & 3 \\
\hline Total & 13 & 2 & 12 & 8 & 35 \\
\hline
\end{tabular}


Table 2 Subthemes and number of incidences for Theme 1: Guiding and assessing student teachers

\begin{tabular}{|l|l|}
\hline Subthemes & Number of incidences \\
& $35 ;$ in 28 of 35 stories \\
\hline Assessment (judgments around pass/fail) & 11 \\
\hline Guiding student teachers' teaching & 13 \\
\hline Providing learning opportunities for student teachers & 5 \\
\hline Teaching student teachers & 6 \\
\hline
\end{tabular}


Table 3 Subthemes and number of incidences for Theme 2: Professionalism, growth and well-being

\begin{tabular}{|l|l|}
\hline Subthemes & Number of incidences \\
\hline Professionalism (teacher educator) & $14 ;$ in 10 of 35 stories \\
\hline Professionalism (student teacher) & 3 \\
\hline Personal growth/identity (teacher educator) & 4 \\
\hline Personal growth/identity (student teacher) & 1 \\
\hline Well-being (student teacher) & 4 \\
\hline
\end{tabular}


Table 4 Subthemes and number of incidences for Theme 3: Collaborative working

\begin{tabular}{|l|l|}
\hline Subthemes & Number of incidences \\
& $18 ;$ in 15 of 35 stories \\
\hline Communication in partnership & 4 \\
\hline Working in partnership across institutions & 11 \\
\hline Working with school leadership & 1 \\
\hline Roles of teacher educators in the partnership & 2 \\
\hline
\end{tabular}


Table 5 Subthemes and number of incidences for Theme 4: Quality of Practice

\begin{tabular}{|l|l|}
\hline Subthemes & $\begin{array}{l}\text { Number of incidences } \\
5 ; \text { in } 5 \text { of } 35 \text { stories }\end{array}$ \\
\hline Quality Assurance & 3 \\
\hline Training for co-ordinating SBTEs & 1 \\
\hline Mentor training & 1 \\
\hline
\end{tabular}

